\title{
Three categories of urban green areas and the effect of their different management on the communities of ants, spiders and harvestmen
}

\author{
Gema Trigos-Peral $^{1}$ (D) $\cdot$ Tomasz Rutkowski $^{2}$ - Magdalena Witek ${ }^{1}$. Piotr Ślipiński ${ }^{1} \cdot$ Hanna Babik $^{1}$. \\ Wojciech Czechowski ${ }^{1}$
}

Published online: 10 March 2020

(C) The Author(s) 2020

\begin{abstract}
Urban green areas have become an important tool for biodiversity conservation in cities. However, land use and the different management practices applied to these areas determine their effectiveness as biodiversity refuges within cities. In our study, we compare the biodiversity of three bioindicator groups of arthropods (ants, spiders and harvestmen) found in eleven urban green sites in Warsaw (Poland). The studied sites represent three categories of management: botanical gardens, public parks and urban woodlands. Our aim was to determine the effect of the type of management (as urban green categories) on arthropod communities in urban areas.
\end{abstract}

Keywords Arthropods $\cdot$ Biodiversity $\cdot$ Community structure $\cdot$ Greenery management $\cdot$ Urban fauna $\cdot$ Urban pressure

\section{Introduction}

The progressive flow of people from the countryside to cities makes the latter a focal points of residence, work and business. This leads to the rapid spatial development of urban agglomerations at the expense of the surrounding rural areas. Such a process drastically reduces suitable habitats for fauna and causes profound and multilateral changes in ecological conditions, both physico-chemical (Chapman et al. 2017; Burdine and McCluney 2019) and biotic ones (e.g. herbaceous vegetation becoming more monocultural). This results in significant differences between the actual fauna of the city and the potential fauna, i.e. the fauna of the surrounding rural areas. In the urban environment, mainly species with strict ecological requirements (specialists: stenotopes, associated to one only

Electronic supplementary material The online version of this article (https://doi.org/10.1007/s11252-020-00949-9) contains supplementary material, which is available to authorized users.

Gema Trigos-Peral

getriral@gmail.com

1 Museum and Institute of Zoology, Polish Academy of Science, Wilcza 64, 00-679 Warszawa, Poland

2 Natural History Collections, Faculty of Biology, Adam Mickiewicz University, Poznań, Umultowska 89, 61-614 Poznań, Poland type of habitat such as i.e. peat bogs, and oligotopes, associated to different habitats of similar type, such as i.e. deciduous forests) are most susceptible to elimination, whereas most resistant are those with the highest tolerance of various habitat conditions (generalists: polytopes, associated a different habitats of one category such as i.e. forests, and eurytopes, species without habitat preferences) (Ślipiński et al. 2012). This leads to the unilateralization of the ecological profile of already depleted individual communities and the deformation of their structure (disproportionately large quantitative shares of dominants over the rest of the community members; Bańkowska et al. 1985; McKinney 2008; Guénard et al. 2015). This, in turn, can lead to a weakening of the homeostatic capacity of the communities, and thus may reduce the resilience of the whole urban ecosystem. On the other hand, urban greenery is a relatively easy target for imported invasive species, mainly spread through the transport of plants and other materials. These species, due to some of their biological properties and their lack of susceptibility to local natural enemies, efficiently colonize new habitats, becoming not only destructive competitors for related native species, but also a serious threat to the functioning of other arthropod communities (Bestelmeyer et al. 2015). In Europe, the ideal example is the ant Lasius neglectus, known within its invasive range almost exclusively from cities (Czechowska and Czechowski 1999; Seifert 2000).

It is obvious that in such an artificial ecosystem as the urban ecosystem, practically the only biodiversity refuges are large green spaces such as parks, gardens and the remnants of 
woodlands preserved within a city (Czechowski 1979; McKinney 2008; MacGregor-Fors et al. 2016). This is why so much depends on the state of these sites - how they are situated, structured, managed and cared for. Focusing in the maintenance labours, green city areas show differences in their landscape according to the manner and intensity of management. Thus, some intensively managed greeneries such as the botanical gardens and some parks, are highly artificial habitats full of exotic plants, while others, like the urban woodlands, are either not managed at all or poorly managed, and so relatively close to natural habitats, as is the case of the urban woodlands.

Interest in the city as an ecosystem and in the urban fauna as such dates back several decades, and has especially increased in recent years. Many individual papers on the species and communities of specific groups of animals (taxocenes) have been published, including those on ants, spiders and harvestmen in various cities of the whole world (e.g. on ants: Czechowski 1991; Antonova and Penev 2008; Ślipiński et al. 2012; Carpintero and Reyes-López 2014; Guénard et al. 2015; Radchenko et al. 2019; on spiders: Krzyżanowska et al. 1981; Magura et al. 2010; Moorhead and Philpott 2013; and on harvestmen: Czechowski et al. 1981; Blick and Komposch 2004; Delfosse and Iorio 2009).

Among the cities most comprehensively studied in terms of the composition and structure of their faunas, Warsaw occupies a prominent place, however, the vast majority of these data are from the turn of the 1970s and 1980s, when comprehensive zoocoenological studies were conducted there (see Czechowski et al. 1981, 1982; Czechowski and Pisarski 1981; Luniak and Pisarski 1982; Luniak 1990; Bańkowska et al. 1985). Warsaw, the largest city of Poland, has 79 public parks under city management with a total area of ca 762 ha (http://zielona.um. warszawa.pl/parki), two botanical gardens, a zoo with its greenery, numerous squares, the greenery of residential estates, along arterial roads, etc. The aforementioned studies in Warsaw showed considerable variation in the arthropod communities in terms of species richness and ecological composition, both between categories of urban greenery and within individual ones. This was especially spectacular in the case of ants (Pisarski and Czechowski 1978; Czechowski 1979, 1991; Pisarski 1982; Czechowski et al. 1990; Czechowski and Pisarski 1990; Ślipiński et al. 2012).

By using the bioindicator character of arthropods, our study aims to evaluate the effect of the manner and intensity of management in urban greenery: i) on the structure of the ant, spider and harvestmen communities in the city, ii) to determine the tasks required to improve the maintenance and conservation of urban greenery, due to the multifaceted values of the urban green areas as the city's lungs, rain water retention, animal refuge and recreational functions (Kabisch et al. 2015, 2016), and iii) to test the influence of invasive species on the native ant biodiversity.

\section{Methods}

\section{Study sites}

A total of 11 study sites in Warsaw urban greenery representing three different ways and intensities of management were selected: botanical gardens, public parks and urban woodland areas (Fig. 1; for the list and descriptions of the individual study sites see Supplementary Online Material 1). The sites were at least several decades old, suggesting that their fauna was quite stably formed. Almost all the study sites were located in the habitat of subcontinental lime-oakhornbeam forest (Tilio-Carpinetum), which is the potential plant community for most of the Warsaw area (see Matuszkiewicz 1966). The exception is the wooded site Morysin, mostly located in alder-ash forest (FraxinoAlnetum) habitat (see Supplementary Online Material 1).

Among the studied urban greenery, the most intensively managed are the botanical gardens. They are subject to frequent horticultural treatments, including mechanical gardening, fertilization, irrigation and chemical plant protection (pesticides). These sites are characterized by a huge richness and diversity of vegetation with a large share of exotic species, but also fairly unstable vegetation (especially of the herb layer) in space and time. Within this category, the two existing botanical gardens in Warsaw were examined, very different in terms of age, area and location: Botanical Garden of the University of Warsaw (WU) and Botanical Garden of the Polish Academy of Sciences (PAS).

Public parks in Warsaw are different-sized green sites, designed mainly in a landscaped style. Open spaces with carefully maintained (although sporadically and locally fertilized, irrigated and treated with pesticides) lawns prevail, which makes the herbaceous vegetation qualitatively very poor; the lawns are regularly mowed, and the mowed grass is removed. The share of flower beds with decorative vegetation is relatively small. In the tree-covered areas, the litter is raked, fallen branches removed, and the trees are tended. Seven public parks were surveyed, representing (relatively small) variations of this category of managed urban green in Warsaw in terms of the manner of its cultivation and intensity of management: Ujazdowski Park, Ogród Saski, Morskie Oko Park, Pole Mokotowskie, Moczydło Park, Szczę́liwicki Park and Ursynów.

Urban woodlands are either remnants of old forests or forest vegetation that developed by the spontaneous succession of neglected, previously managed greenery sites; now practically lacking any maintenance. The two existing sites of this category within the city were studied: Fort Bema and Morysin.

\section{Sampling design and material}

The field work was conducted at the end of July and beginning of August 2014, using pitfall traps as the sampling method. 


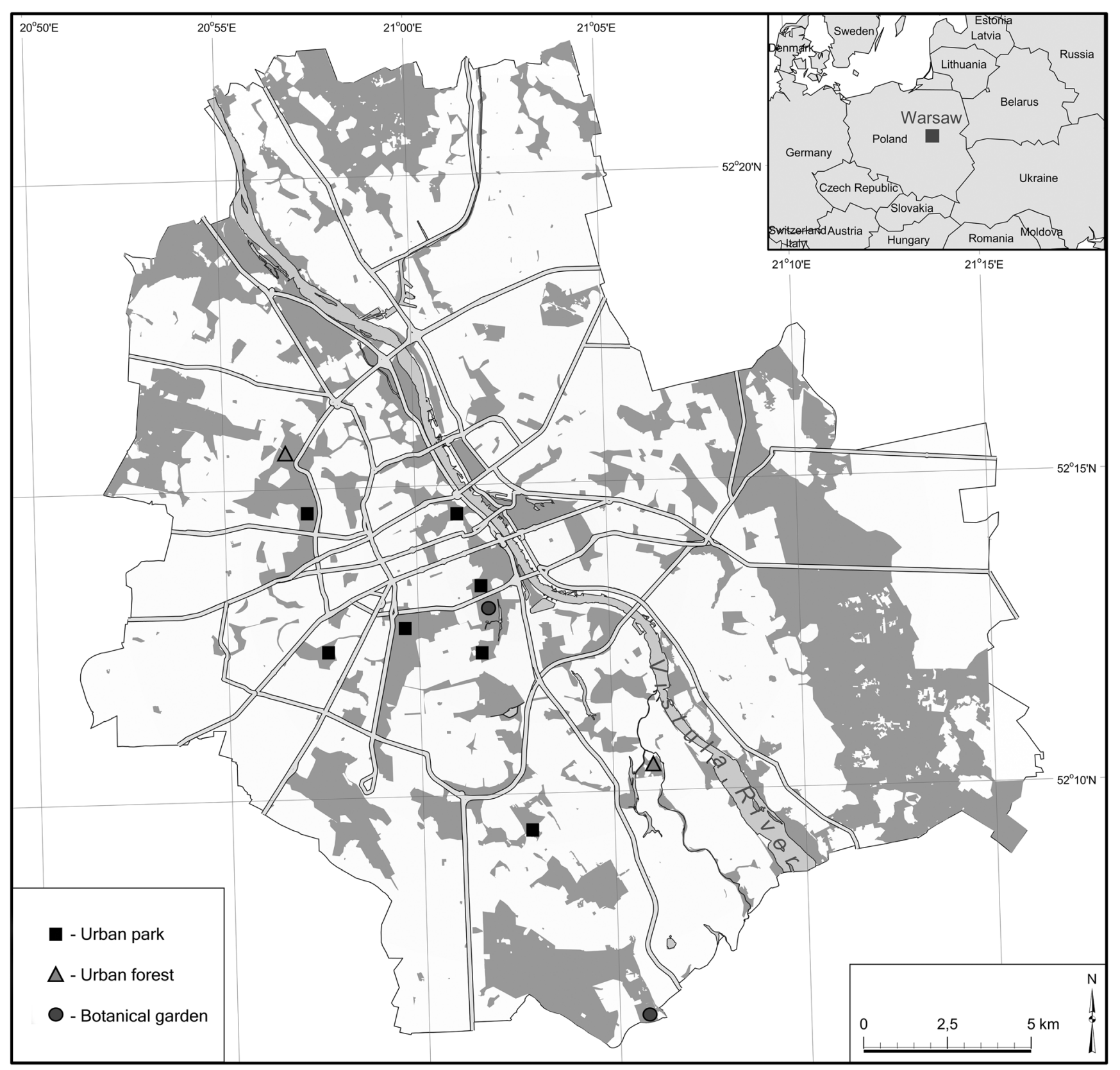

Fig. 1 Map of the studied greeneries in Warsaw

The traps were semitransparent plastic cups $(5.6 \mathrm{~cm}$ in diameter, $7 \mathrm{~cm}$ in depth) filled with $30 \mathrm{~cm}^{3}$ of water with a drop of common dishwashing detergent, buried at ground level. In each site studied, we placed four transects of 10 traps per transect and we kept them working during four days. Pitfall traps were separated $10 \mathrm{~m}$ from each other and the closest transects were separated a minimal distance of $50 \mathrm{~m}$ and a maximal distance of $160 \mathrm{~m}$ from each other. Due the homogeneity of the temperatures during the months of July and August in Warsaw, warm rainless days with approximately the same temperature were selected for the sampling of all sites. In total, 440 traps were set, material was obtained from
437 of them (3 traps were lost; 1 trap in Fort Bema and 2 traps in Pole Mokotowskie).

In the laboratory, invertebrates of the three groups studied were selected from the total content of the traps. In the case of ants, only workers were taken into account. The material obtained had 12747 individuals: 10536 ants, 537 spiders and 1674 harvestmen (see Supplementary Online Material 2, Tables 1, 2, 3). All individuals were identified to species, with the exception of two ant specimens (belonging to two different species) of the genus Temnothorax. The keys of Czechowski et al. (2012) for ants, Haase and Balkenhol (2015) and Oleszczuk (2017) for spiders, and Nentwig et al. (2018) for 
Table 1 GLMM of differences in abundance of ant species among the three studied urban greeneries

\begin{tabular}{lccccc}
\hline \multirow{2}{*}{ Species } & \multicolumn{2}{c}{ Botanical G - Parks } & & \multicolumn{2}{l}{ Woodlands - Parks } \\
\cline { 2 - 3 } \cline { 6 - 7 } & $\mathrm{Z}$ & $\mathrm{p}$ & & $\mathrm{Z}$ & $\mathrm{p}$ \\
\hline L. niger & $\mathbf{2 . 5 9}$ & $\mathbf{0 . 0 1}$ & & $\mathbf{- 2 . 0 5}$ & $\mathbf{0 . 0 4}$ \\
M. rubra & $\mathbf{1 . 2 6}$ & $\mathbf{0 . 0 2}$ & & 0.05 & 0.95 \\
T. crassispinus & 0.35 & 0.72 & & 0.98 & 0.32 \\
M. ruginodis & 1.19 & 0.24 & & $\mathbf{1 . 9 8}$ & $\mathbf{0 . 0 5}$ \\
D. quadripunctatus & 0.68 & 0.49 & & $\mathbf{2 . 3 5}$ & $\mathbf{0 . 0 2}$ \\
F. fusca & $\mathbf{2 . 9 5}$ & $\mathbf{0 . 0 0 3}$ & & $\mathbf{2 . 3 6}$ & $\mathbf{0 . 0 2}$ \\
L. platythorax & $\mathbf{2 . 9 3}$ & $\mathbf{0 . 0 0 3}$ & & $\mathbf{2 . 1}$ & $\mathbf{0 . 0 4}$ \\
L. flavus & $\mathbf{2 . 1 7}$ & $\mathbf{0 . 0 3}$ & & -1.36 & 0.17 \\
T. caespitum & $\mathbf{2 . 1 9}$ & $\mathbf{0 . 0 2}$ & & 1.645 & 0.09 \\
\hline
\end{tabular}

*In bold the significant $p$-values

harvestmen were used for the identification and ecological categorization of the species.

\section{Data analysis}

Among the native ant and spider species, generalists (eurytopes + polytopes) and specialists (oligotopes + stenotopes) were distinguished. Moreover, the category of exotic invasive species was distinguished for these two groups based on the list of invasive species in Poland; http://www. europe-aliens.org/regionFactsheet.do? regionId = POL). Harvestmen were not categorized due the general anthropophilic tendency of the species found.

For ants, statistical analyses were conducted using frequency data, i.e. the number of traps (and not individuals) containing individuals of a given species, in order to avoid the bias resulting from an overstated number of individuals due to accidental placement of the trap in the immediate vicinity of a nest. For spiders and harvestmen, as solitary arthropods,

Table 2 GLMM of differences in abundance of spider species among the three studied urban greeneries. Only the most abundant species and those one with significant results are represented in the table

\begin{tabular}{lcccrr}
\hline Species & \multicolumn{2}{c}{ Botanical G - Parks } & & \multicolumn{2}{c}{ Woodlands - Parks } \\
\cline { 2 - 3 } \cline { 6 - 7 } & $\mathrm{Z}$ & $\mathrm{p}$ & & $\mathrm{Z}$ & $\mathrm{p}$ \\
\hline O. praticola & -0.74 & 0.46 & & -0.664 & 0.51 \\
D. concolor & 1.060 & 0.29 & & $\mathbf{2 . 9 6 8}$ & $<\mathbf{0 . 0 1}$ \\
E. dentipalpis & 1.060 & 0.29 & & $\mathbf{- 1 . 9 2 6}$ & $\mathbf{0 . 0 5}$ \\
M. subaequalis & $\mathbf{1 . 9 4 2}$ & $\mathbf{0 . 0 5}$ & & -0.003 & 0.99 \\
T. ruricola & $\mathbf{2 . 2 3 3}$ & $\mathbf{0 . 0 2 5}$ & & -1.134 & 0.26 \\
X. miniata & $\mathbf{2 . 8 1 0}$ & $<\mathbf{0 . 0 1}$ & & 1.299 & 0.19 \\
T. flavipes & $\mathbf{2 . 4 6 7}$ & $\mathbf{0 . 0 1 4}$ & $\mathbf{3 . 4 7 5}$ & $<\mathbf{0 . 0 0 1}$ \\
\hline
\end{tabular}

*In bold the significant p-values analyses were conducted based on abundance data, i.e. the number of captured individuals. Each group was analyzed separately. The diversity of ants, spiders and harvestmen in each category was evaluated using the Shannon-Wiener Diversity Index. Species richness was calculated by using the functions diversity and specnumber in the BiodiversityR R-package (Kindt and Coe 2005). Each transect of 10 pitfall traps placed within the studied sites were used as a unit of measurement for diversity and species richness. The obtained values were used to test differences in diversity and species richness among the three categories of urban greenery by using Linear Mixed Models (LMM), performed with the R 3.4.2 statistical package (R Core Team, 2017). The models were carried out by using the lmer function in the nlme Rpackage (Pinheiro et al. 2017). The values of the ShannonWiener Diversity Index and species richness were used as variables (in two separated models), the category of urban greenery (Botanical Garden, Public Park or Urban Woodland) as the fixed factor and the identity of the transect was used as random factor.

To visualize the differences in ant, spider and harvestmen communities among the three categories of urban greenery, the linear discriminant analysis was performed using the $l d a$ function in the MASS R-package (Venables and Ripley 2002). The number of pitfall traps containing a given species of ants, and the number of individuals of each species of spiders and harvestmen trapped in each studied site were used as variables of spiders and were used as variables, whereas the each category was used as the fixed factor. The contribution to the dissimilarities of each species was calculated with the SIMPER test by using the simper function in the Vegan Rpackage (Oksanen et al. 2017) on the matrix of traps with each species, with the category of greenery as the grouping variable. In the case of spiders and harvestmen, the matrix was built with the number of individuals instead of the number of traps.

As the next step, we analysed the effect of each category of the urban greenery on the ecological categories of the bioindicator groups (generalist and specialist ants and spiders, and exotic species only for ants - because this was the only group with sufficient number to perform the statistical analyses) with the Generalized Linear Mixed Model approach (GLMM, Poisson error, maximum likelihood) by using the glmer function in the nlme R-package. To develop the model, the number of pitfall traps containing representatives of each bioindicator group in the case of ants and the number of individuals in the case of spiders were introduced as the variable, each urban green category as the fixed factor, and the identity of each studied site as the random factor. Only shares of specialist and generalist ants and spiders were analyzed due the negligible number of exotic species in both groups. The same approach (GLMM, Poisson error, maximum likelihood) was used to test the influence of the type of management (urban 
green category) on each independent species. The proportion of specialist species for each urban green category was calculated by dividing the number of pitfall traps occupied with specialist species by the total number of pitfall traps. Due to its high ecological plasticity, the species of harvestmen found in our study were not classified into bioindicator groups to avoid an incorrect categorization of species in functional groups and, consequently, the inappropriate evaluation of the study areas.

Finally, the effect of the invasive garden ant Lasius neglectus on the most abundant native ant species was analysed with the Linear Mixed Model approach (LMM) by using the lmer function in the nlme R-package and lmerTest Rpackage (Kuznetsova et al. 2017). Both, the abundance of individuals of each of the considered native species was used as the variable and the abundance of L. neglectus as the explanatory variable, while the identity of each studied transect was used as the random factor. To increase the reliability of the test, only ant species with a high abundance in the sites with L. neglectus were used for the analyses. The test was performed only with the data collected in Ujazdowski Park, the sampled greenery with a strong presence of this invasive species.

The Bonferroni correction of the significance levels for the multiple comparisons conducted by using LMMs and GLMMs was carried out by using the function ghlt in the multcomp R-package (Hothorn et al. 2008). All graphic presentations were performed using the ggplot function in the ggplot2 R-package (Wickham 2009). Adjustments in the $x$ axis aesthetic were made by using str_wrap in the stringr Rpackage (Wickham 2017). Multipanels were arranged by using the grid.arrange function in the gridExtra R-package (Auguie 2017).

\section{Results}

We recorded 34 species of ants, 83 species of spiders and 11 species of harvestmen in the urban greenery of Warsaw (see Supplementary Online Material 2 Tables 1, 2, 3). Within each of these groups of arthropods, the occurrence of some species was limited to one or two categories of greenery, while others occurred in all categories, and even in all or almost all of the studied sites.

\section{Ants}

Ants were the most abundant group studied in the Warsaw greenery, and second in species richness: 34 species were found (ca. $35 \%$ of all Polish outdoor myrmecofauna). In the material obtained from individual greenery sites, the number of ants varied from 185 individuals in the (small) UW Botanical Garden to 2649 individuals in the Morysin woodland. The object poorest in ant species was Morskie Oko Park (10 species), the richest - the (large) PAS Botanical Garden (20 species); $29 \%$ and $59 \%$ of the total species pool respectively. Three species definitely prevailed in the examined urban greenery as a whole: Lasius niger, a polytope of open habitats (49.8\%), Myrmica rubra, a eurytope (14.0\%) and Temnothorax crassispinus, an oligotope of coniferous forests $(12.3 \%)$. Lasius niger (with shares of $82.3-$ $42.7 \%$ ) dominated in the ant communities of almost all (except two) examined green sites. Two foreign (imported) ant species were recorded: Lasius neglectus (in Pole Mokotowskie and Ujazdowski parks) and Pheidole megacephala in the UW Botanical Garden (first record in Poland; one worker found outdoors). Lasius neglectus dominated the Ujazdowski Park (47.9\% of its myrmecofauna), outnumbering the native L. niger (see Supplementary Online Material Table 1).

Statistical analyses revealed that the three categories of urban greenery with different management intensities differed in ant community composition. The significant differences are manifested in the results of the LDA (Fig. 2a). Statistical significance was also revealed with a percentage of dissimilarity (SIMPER) of $58.8 \%$ between the botanical gardens and public parks, $90.9 \%$ between the botanical gardens and urban woodlands, and $92.8 \%$ between the woodlands and parks.

Results from the GLM revealed significant differences in the values of the Shannon-Wiener diversity index between ant communities in the public parks and both the botanical gardens $(\mathrm{t}=3.925, p<0.001)$ and the urban woodlands $(\mathrm{t}=2.686, p=0.01)$. No significant differences were found between the botanical gardens and the woodlands $(\mathrm{t}=-1.398, p=0.17$ ) (Fig. 2b). In terms of species richness, significant differences were found between the communities in the public parks and the botanical gardens $(\mathrm{t}=4.880, \mathrm{p}<$ $0.001)$ and in the urban woodlands $(\mathrm{t}=2.093, p=0.04)$, as well as between the communities in the botanical gardens and the woodlands $(\mathrm{t}=-2.646, \mathrm{p}=0.01)$ (Fig. $2 \mathrm{c})$.

The proportion of specialist species in the total ant species richness was $28.6 \%$ in the botanical gardens, $28.1 \%$ in urban woodlands and only $7.24 \%$ in public parks. Differences in the distribution of the distinguished ecological groups of species, i.e. generalists and specialists, were also found when comparing the number of their species in the three categories of greenery. In the case of generalist species, no significant differences were found when comparing public parks with the botanical gardens $(Z=1.10, p=0.27)$ and with urban woodlands $(Z=-1.15, p=0.25)$. Significantly lower number of generalist species were found in woodlands compared to botanical gardens $(Z=-2.135, p=0.03)$. On the other hand, specialist species favoured the botanical gardens $(Z=7.889, p>0.001)$ and woodlands $(Z=7.498, p>0.001)$ when compared with public parks, and no differences were found between the botanical gardens and woodlands $(Z=-0.661, p=0.51)$ (Fig. 3). 


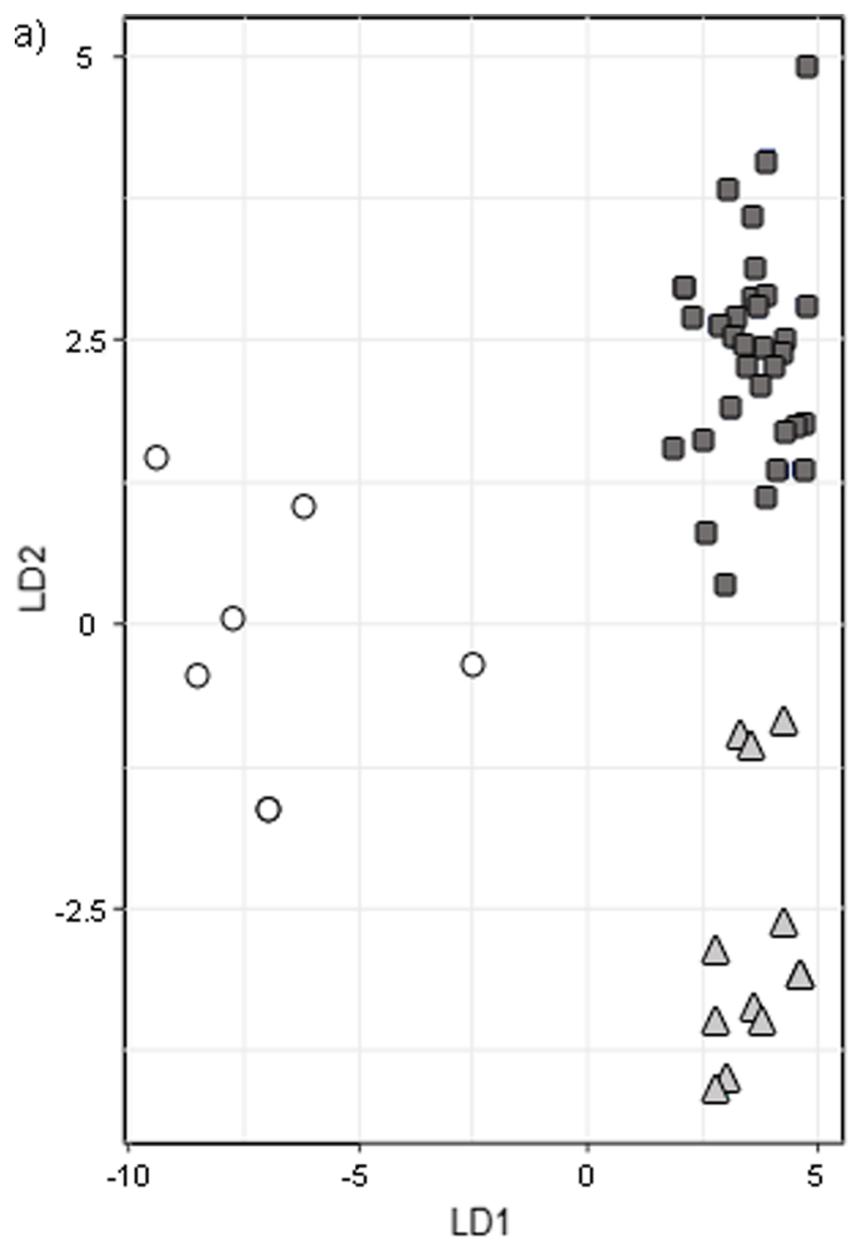

O Botanical Garden

$\triangle$ Urban Woodland

Public Park
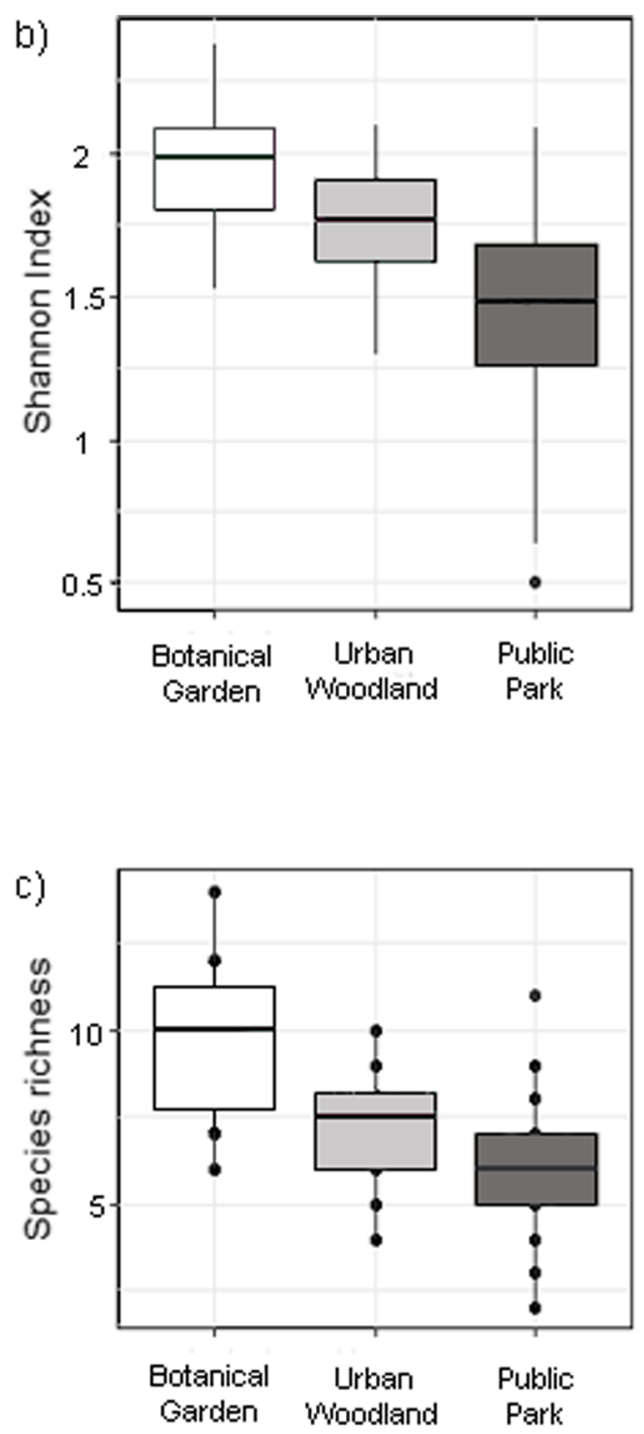

Fig. 2 Graphical representation of the Linear Discriminant Analyses (LDA) (a), boxplot of Shannon biodiversity Index (b) and boxplot of Species richness (c) of the ant community in the studied sites of the three categories of urban greenery

The manner and intensity of management, different among the studied categories, affect the most abundant individual species in different ways. The management of urban woodlands $(\mathrm{Z}=-2.592, p=0.01)$ and the botanical gardens $(\mathrm{Z}=$ $-2.053, p=0.04)$ negatively affects the occurrence of $L$. niger when comparing these greeneries with public parks, whereas no differences were found between the woodlands and botanical gardens $(\mathrm{Z}=-0.071, p=0.94)$. In addition, significant differences in the abundances of some of the most numerous species were found among the three categories of the urban greeneries (Table 1, Fig. 4). No significant results were found for the other ant species among the three urban greeneries with different management practices.

The three most abundant native ant species (Lasius niger, Myrmica rubra, Temnothorax crassispinus) were found to respond differently in their interaction with Lasius neglectus in Ujazdowski Park, which had a strong presence of this invasive ant species. $L$. niger and $M$. rubra were negatively correlated with the presence of $L$. neglectus $(\mathrm{Z}=-12.188$, $p<0.001$, and $Z=-2.135, p=0.03$; respectively), whereas T. crassispinus was found to be positively correlated with its presence $(\mathrm{Z}=2.981, \mathrm{p}=0.03)$ (Fig. 5).

\section{Spiders}

In terms of the number of individuals trapped, spiders were the least abundant arthropod group studied in Warsaw. At the same time, the 83 species found $(10.3 \%$ of the Polish arachnofauna) were the most diverse in terms of species richness. The material obtained from individual greenery sites varied from 21 individuals in Szcześliwicki Park to 104 individuals in the (small) WU Botanical Garden. The site poorest 


\section{Specialist species}

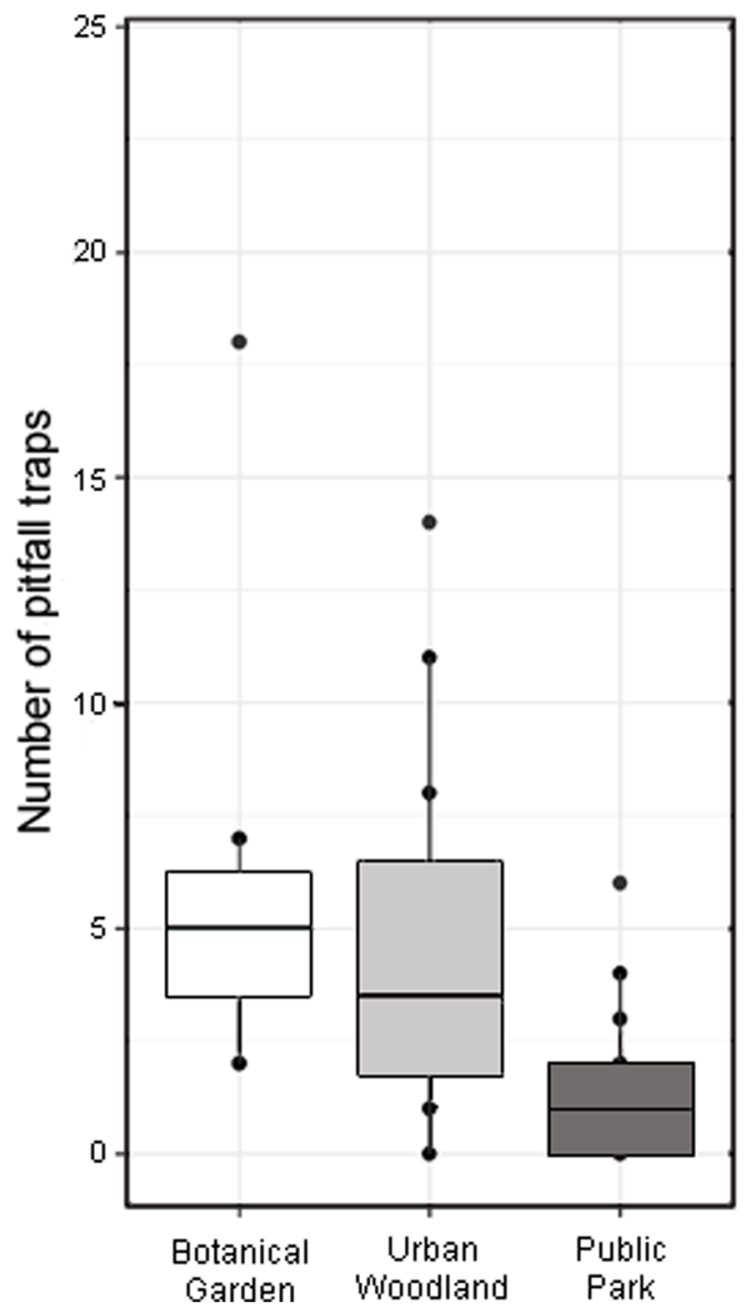

Generalist species

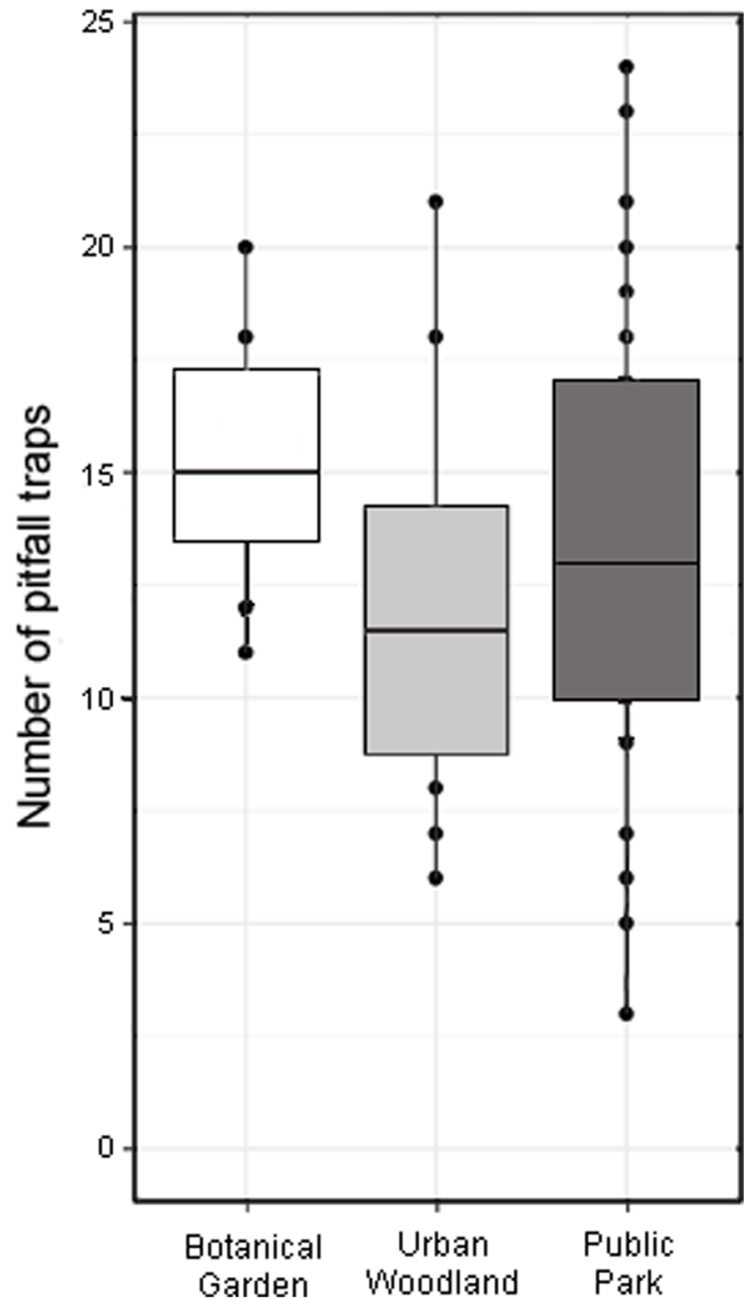

Fig. 3 Boxplot of number of specialist and generalist ant species found in the studied sites of the three categories of urban greenery

in species was WU Botanical Garden (10 species), and the richest - PAS Botanical Garden (41 species). The most abundant species in the Warsaw greenery as a whole were: Ozyptila praticola, a polytope of forests (16.2\%), Diplostyla concolor, an oligotope of calcareous grasslands (9.3\%), Tenuiphantes flavipes, a polytope of forests (6.3\%), as well as Erigone dentipalpis and Diplocephalus cristatus, both polytopes of grasslands (6.2\% and 5.8\% respectively). Ozyptila praticola (with shares of 28.9-12.1\%) dominated in the spider communities in six of the eleven examined sites. Four different species dominated in the spider communities of the other five sites. In the PAS Botanical Garden and the Fort Bema woodland, the dominant was Xerolycosa miniata (13.5 and 26.1\% respectively). Erigone dentipalpis (18.0\%) prevailed in Morskie Oko Park, Diplostyla concolor (29.3\%) in Morysin woodland and Diplocephalus cristatus $(17.7 \%)$ in Ogród Saski Park. One individual of Mermessus trilobatus, a foreign invasive spider species, was trapped in Ogród Saski Park (see Supplementary Online Material 2 Table 2).

The three different categories of urban greenery differed in their spider species composition. The graphical representation of the Linear Discriminant Analysis shows the different community compositions of the botanical gardens, public parks and urban woodlands (Fig. 6a). The percentage of dissimilarity (SIMPER) was $79.2 \%$ between the botanical gardens and public parks, $86.6 \%$ between botanical gardens and woodlands and $92.8 \%$ between urban woodlands and public parks.

Differences in the diversity and species richness of spider communities were found among the three studied categories of management. Results of the GLM showed significantly higher Shannon-Wiener diversity index values of the spider communities in the botanical gardens when compared with public parks $(\mathrm{t}=2.517, p=0.01)$, but no significant differences between public parks and woodlands $(\mathrm{t}=-1.947, p=$ 


\section{Lasius niger}

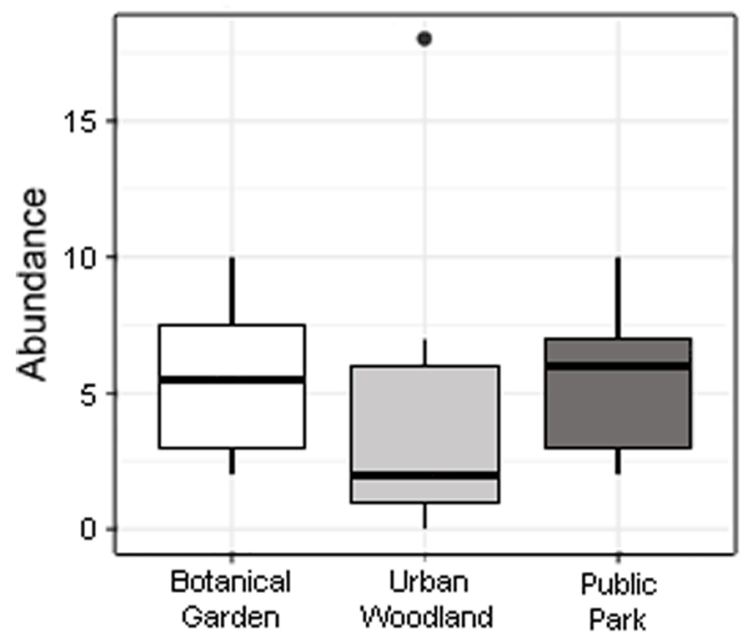

Tetramorium caespitum

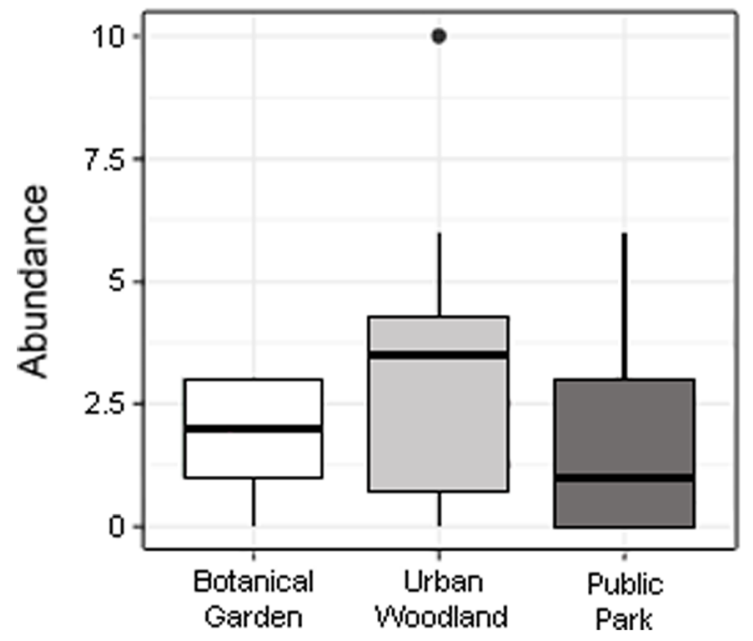

Myrmica rubra

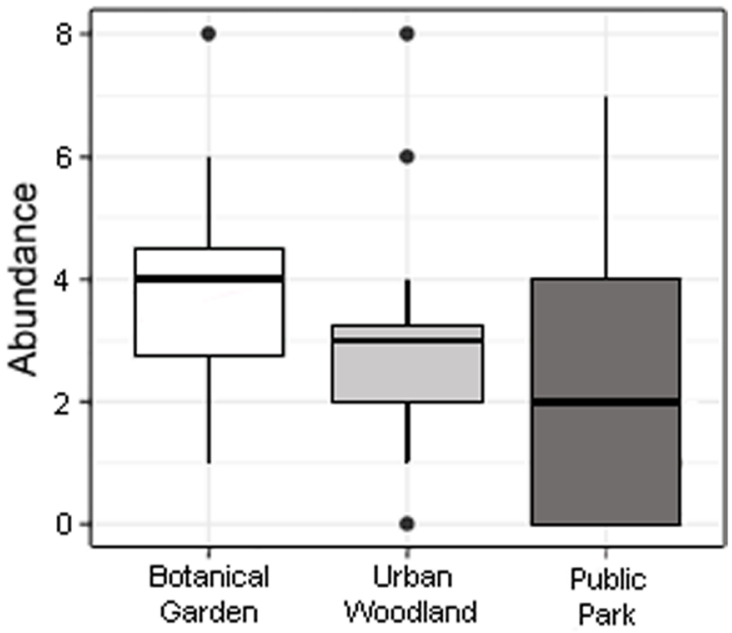

Fig. 4 Boxplot of the most abundant ant species in the studied sites of the three categories of urban greenery

0.06) (Fig. 6b). The species richness was significantly lower in parks than in the botanical gardens $(\mathrm{t}=3.735, p<0.001)$, but no significant difference was found in this respect between public parks and woodlands $(\mathrm{t}=-1.474, p=0.15)$ (Fig. 6c). When testing the bioindicator groups, the proportion of specialist species was $9.9 \%$ in the botanical gardens, $7.7 \%$ in parks and $7.1 \%$ in urban woodlands. The number of individuals of specialists species in the pitfall traps was significantly higher in the botanical gardens $(Z=4.70, p=0.007)$ than in public parks, but no significant difference was found between public parks and woodlands $(Z=0.347, p=0.73)$. In the case of the group of generalist species, the highest number of pitfall traps containing them was found in the botanical gardens in comparison with public parks $(\mathrm{Z}=2, p=0.04)$. Nevertheless, even with its low representation, no significant differences were found between public parks and woodlands $(\mathrm{Z}=$ $-1.252, p=0.21$ ) (Fig. 7). Moreover, differences in abundance of spiders among the three urban green categories on a group of the 7 most abundant spider species, and showed significant differences in this respect (Table 2, Fig. 8).

\section{Harvestmen}

Harvestmen were second in terms of abundance but the least rich in species among the groups of arthropods studied in Warsaw. Eleven species were found $(35.5 \%$ of Polish opiliofauna). As many as 10 (90.9\%) of them were present in public parks. The material obtained from individual greenery sites varied from four individuals in PAS Botanical Garden to 648 individuals in Moczydło Park. The sites poorest in harvestmen species were PAS Botanical Garden and Szcześliwicki Park (2 species in each), the richest - Pole Mokotowskie Park (7 species). Oligolophus tridens explicitly 


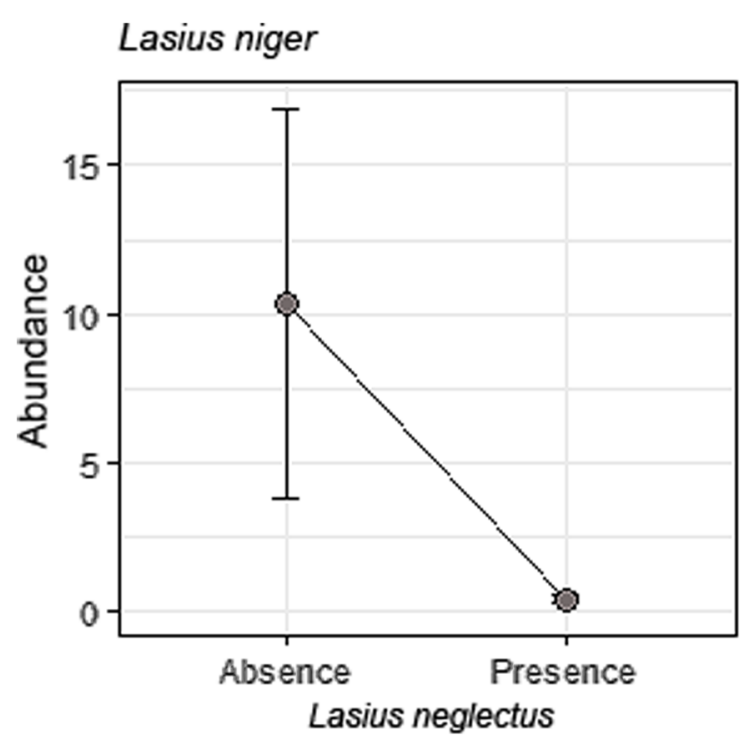

Myrmica rubra

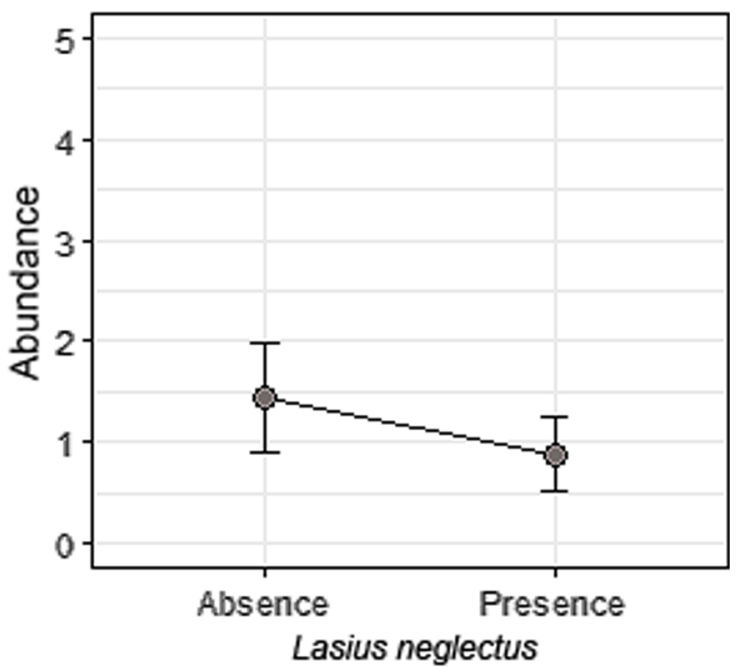

Temnothorax crassispinus

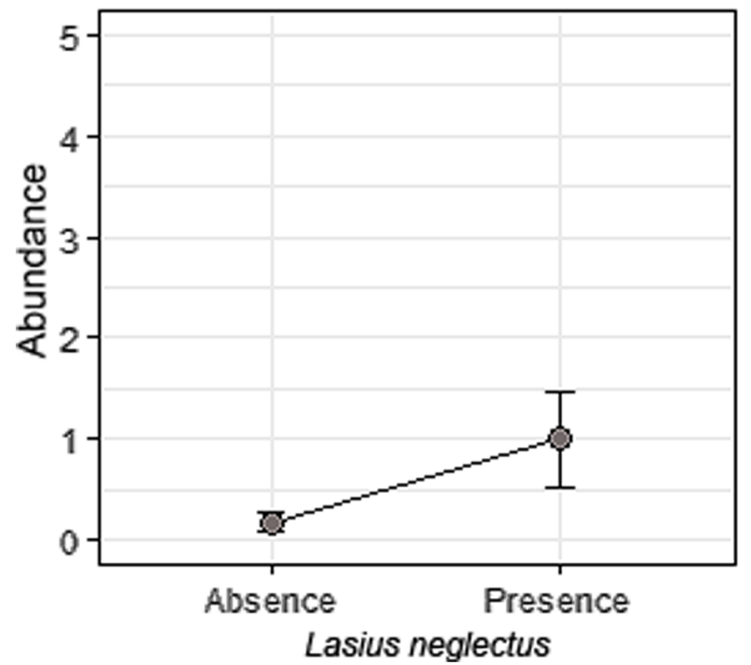

Fig. 5 Mean and error bars representation of the effect of Lasius neglectus on the most abundant ant species found in Ujazdowski Park

prevailed (69.2\%) in the examined urban greenery as a whole. Second on the list (14.2\%) was Opilio canestrinii. The latter, as well as Nelima semproni, are two invasive harvestmen species found in the urban greenery of Warsaw, both were present in all studied habitats with each category. At least one of them occurred in all the studied sites except Szcześliwicki Park (see Supplementary Online Material 2 Table 3).

Oligolophus tridens (with shares of 96.2-47.5\%) dominated in the harvestmen communities of eight of the eleven examined sites. In the remaining ones, the dominants were: Phalangium opilio in Fort Bema woodland (42.86\%), Opilio canestrinii in Ogród Saski Park (48.1\%), and the PAS Botanical Garden, where Lacinius horridus and the invasive Nelima semproni occurred in the same proportion (50\% each).

Differences in the harvestmen community composition among the studied urban greenery categories under different management practices are visible throughout the graphical presentation of the LDA (Fig. 9a). The percentage of dissimilarity (SIMPER) was $85.9 \%$ between the botanical gardens and public parks, $82.7 \%$ between botanical gardens and woodlands and $84.2 \%$ between urban woodlands and public parks.

When testing the differences of the Shannon-Wiener diversity index values, no significant differences were found for any of the pairwise comparisons between the three categories of urban greeneries (botanical gardens vs. public parks: $\mathrm{t}=$ $-0.789, p=0.43$; public parks vs. woodlands: $\mathrm{t}=-1.12, p=$ 0.27 ; botanical gardens vs. woodlands; $\mathrm{t}=-0.076, p=0.94$ ) (Fig. 9b). Also, no significant differences were found in species richness when performing the GLM to compare botanical gardens and public parks $(\mathrm{t}=-1.625, p=0.11)$, public parks and woodlands $(\mathrm{t}=-1.189, p=0.24)$, and botanical gardens 
a)

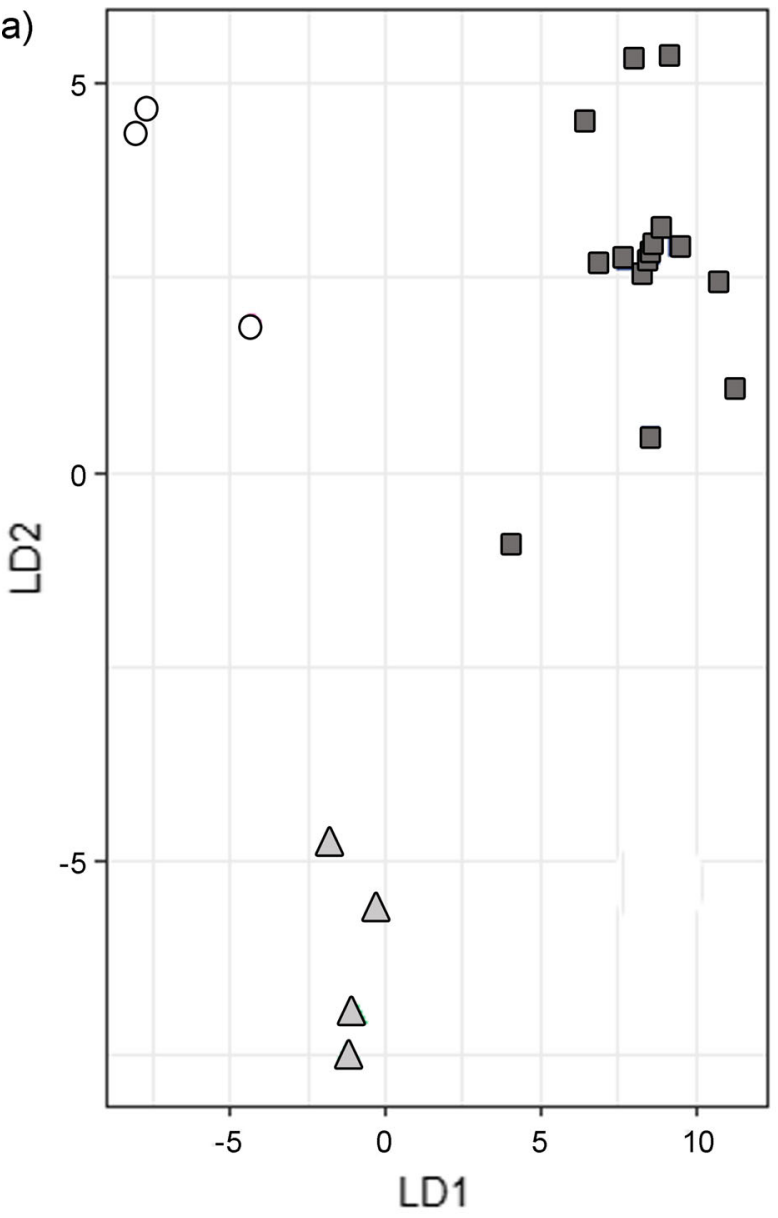

O Botanical Garden

$\triangle$ Urban Woodland

Public Park

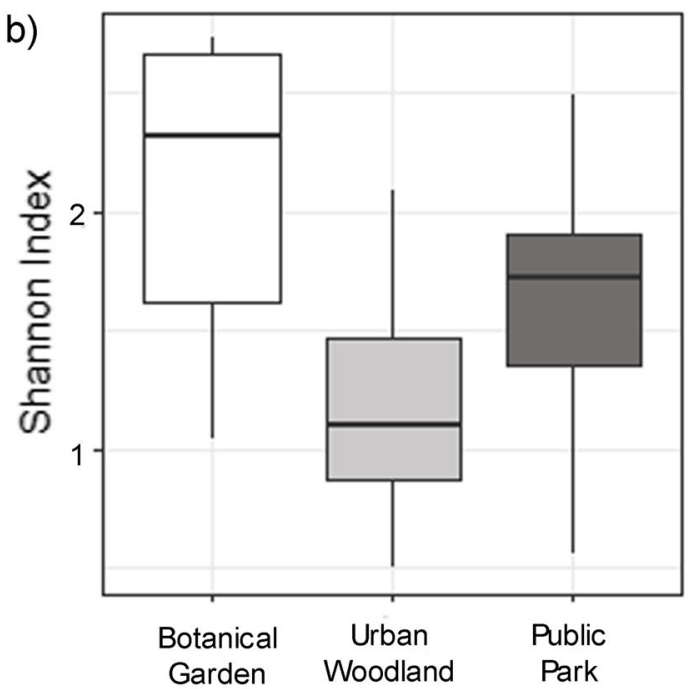

c)

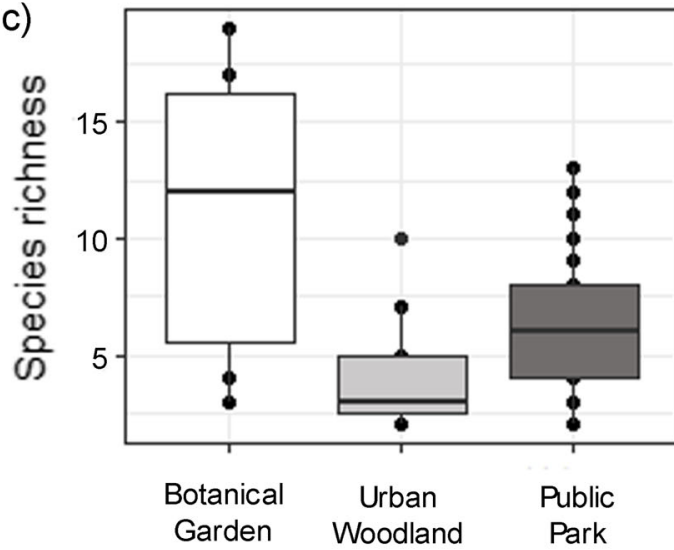

Fig. 6 Graphical representation of the Linear Discriminant Analyses (LDA) (a), boxplot of Shannon biodiversity Index (b) and boxplot of Species richness (c) of the spider community in the studied sites of the three categories of urban greenery

and woodlands ( $\mathrm{t}=0.605, p=0.55)$ (Fig. 9c). When the effect of the presence of the invasive species Opilio canestrinii on native harvestmen species was tested, no significant result was obtained for any case.

\section{Discussion}

Our study shows, for the first time, the relevance of green areas as a refuge of arthropod diversity in the urban environment, as well as the relevance of the type and intensity of management (different among the studied categories) of these areas using the example of three groups of arthropods: ants, spiders and harvestmen. Thirty-three ant species (apart from an unclear case of the exotic Pheidole megacephala; see below), which were found in 11 surveyed green areas of
Warsaw, constitute more than half (54\%) of the entire outdoor myrmecofauna of the Mazovian Lowland (see Czechowski et al. 2012) - taking into account the entire habitat diversity of the region. Not only is the myrmecofauna of Warsaw as such characterized by relatively large species richness, but also the ant communities of the individual urban greenery sites studied, for which the average number of species is 13.9 ( \pm 2.84). In previous studies carried out in Warsaw in the 70s and 80 s of the last century by B. Pisarski and W. Czechowski (e.g. Pisarski and Czechowski 1978; Pisarski 1982; Ślipiński et al. 2012), a total number of 27 ant species were found in the study greeneries. Our study increases this number in three native Lasius species present in other locations in Poland (L. platythorax, L. alienus and L. paralienus) plus two exotic ant species, Lasius neglectus and Pheidole megacephala, both 


\section{Specialist species}

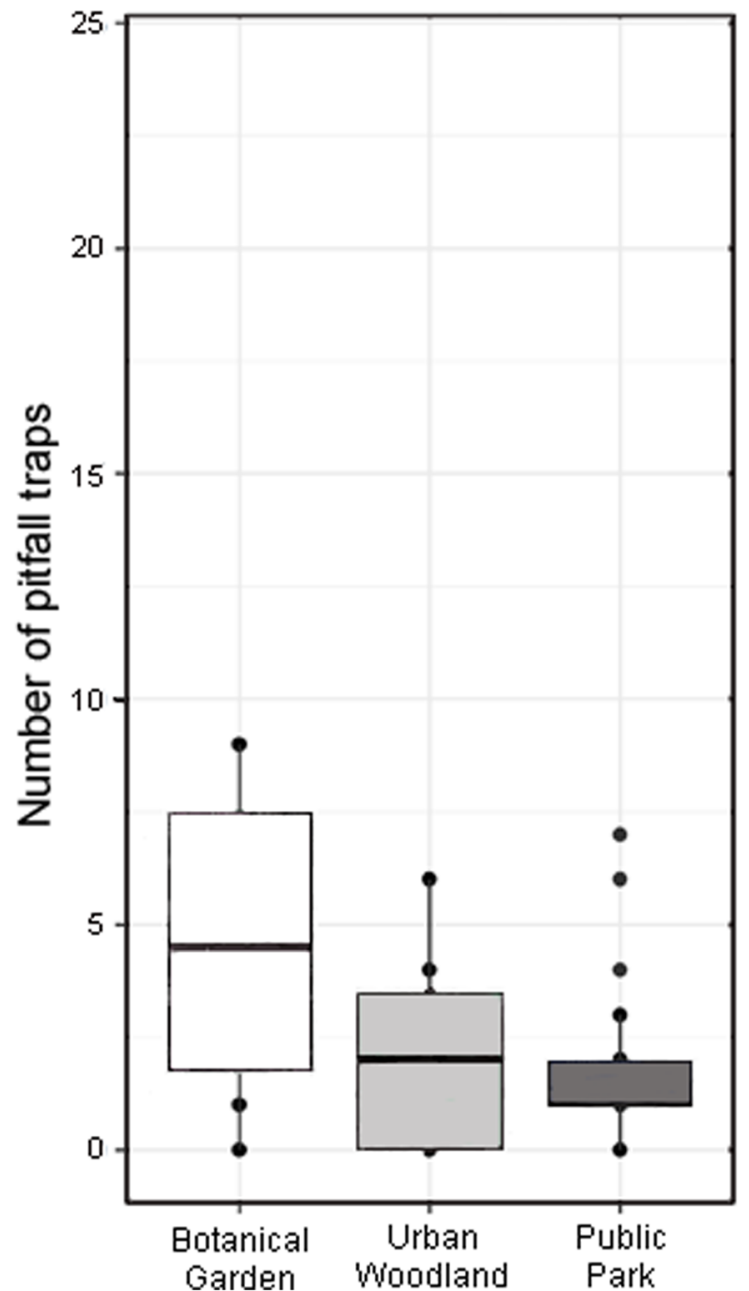

Generalist species

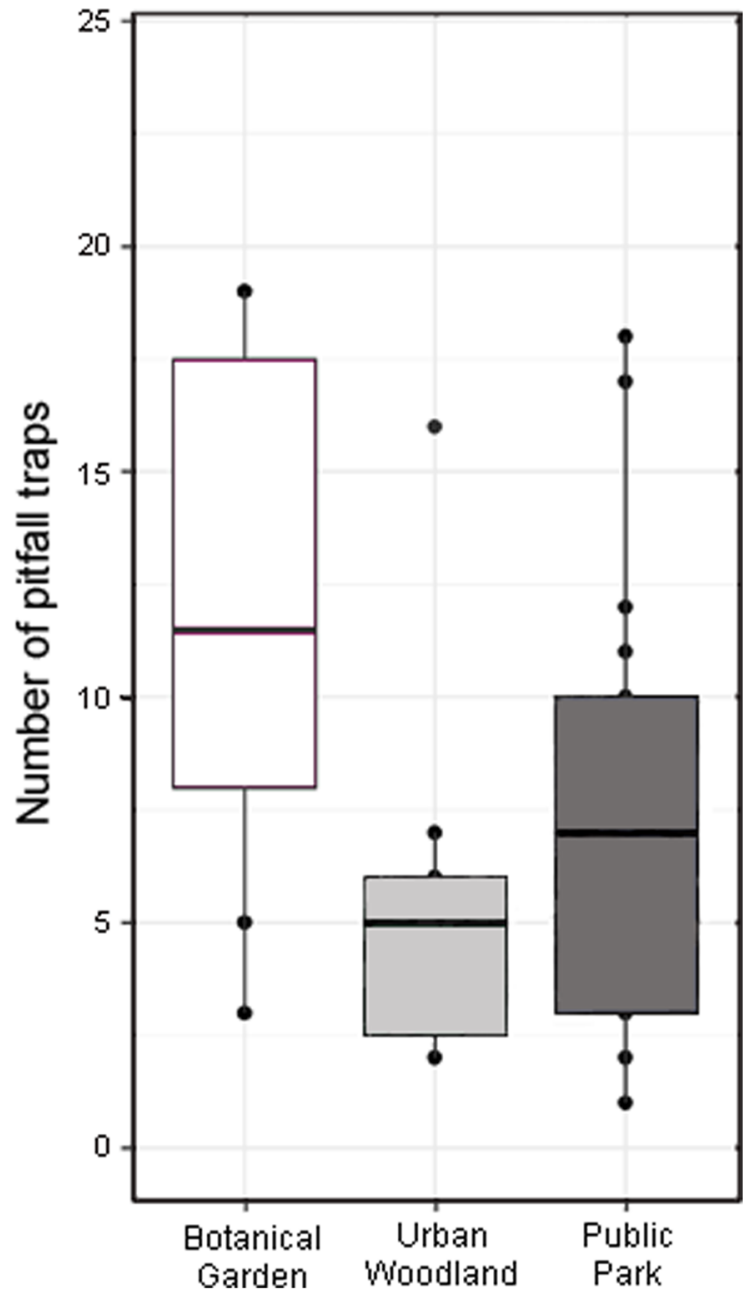

Fig. 7 Boxplot of number of specialist and generalist spider species found in the studied sites of the three categories of urban greenery

considered invasive. These last two new findings are the most relevant since the appearance of these two species in the city is an undoubted effect of the human activity.

For spiders and harvestmen, the relative species richness in urban greenery also seems to be very high. A total number of 83 spider species, with an average of $20.1( \pm 8.04)$ per a greenery site, was recorded, which is $32.7 \%$ of the arachnofauna known within the administrative boundaries of Warsaw (see Krzyżanowska et al. 1981; Wawer 2016). In the case of harvestmen, the total of 11 species present in our study constitute $68.7 \%$ of the opiliofauna known within the administrative boundaries of Warsaw (see Czechowski et al. 1981; Starega 2004; Rozwałka and Starega 2012). An average of 4.6 $( \pm 1.75)$ species were found in each studied site. The presence of the alien species Nelima semproni in Warsaw was confirmed after more than 40 years from the first record (Czechowski and Staręga 1977).
In urban ecosystems, the level of biodiversity is largely related to the habitat structure and plant composition of a green area (see e.g. Czechowski et al. 1981; Dauber and Eisenbeis 1997; Vepsäläinen et al. 2008; Trigos-Peral 2015). These factors play an important role, as their variability is directly correlated with the abundance of resources (food, shelters, etc.) available for various animals, and are especially important when habitat size is limited, as is the case with fragmented urban greenery. Therefore, a mozaic landscape composed of wooded, herb, grassy and bare patches, as well as a large variety of plants offer suitable conditions for animal species with both a broad and narrow ecological spectrum.

The results obtained in our study reveal a clear relationship between the shape of the communities of all three studied groups of arthropods and the form and intensity of management practices applied in the urban greenery. Whereas ants and spiders display similar trends among the three categories, 
Diplostila concolor

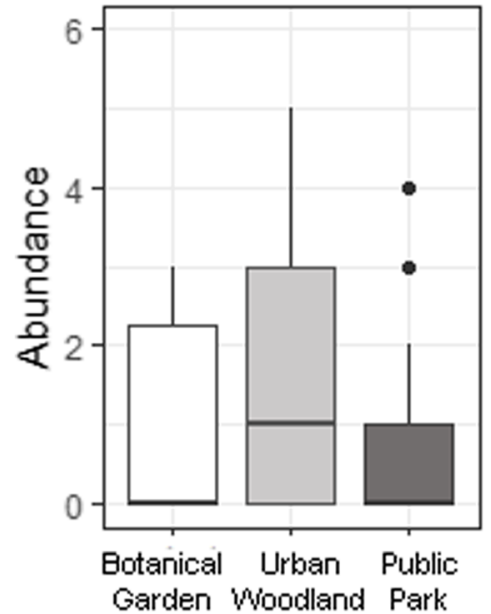

Xerolycosa miniata

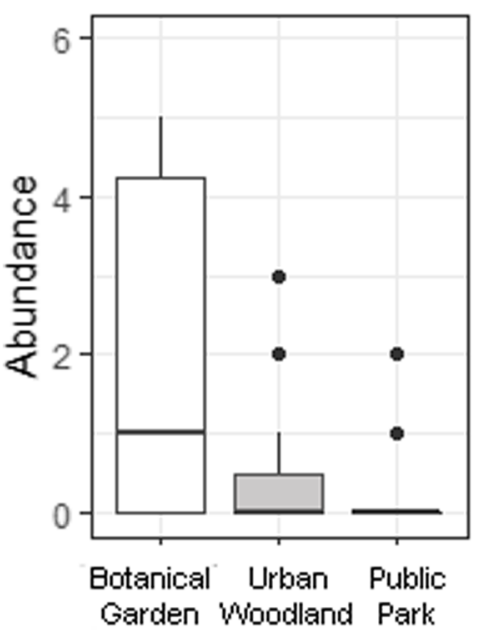

Tenuiphantes flavipes

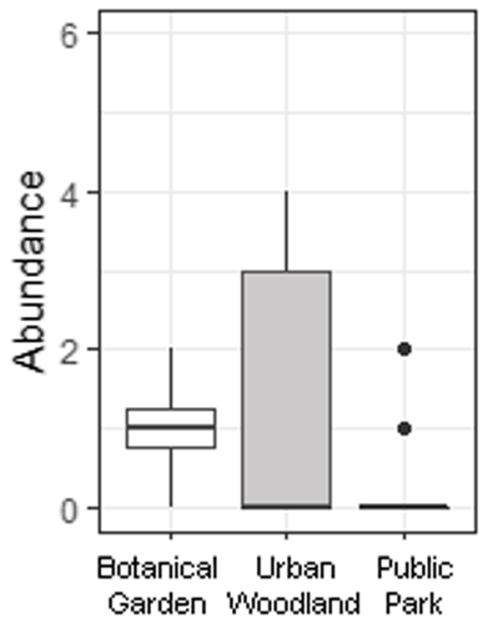

Trochosa ruricola

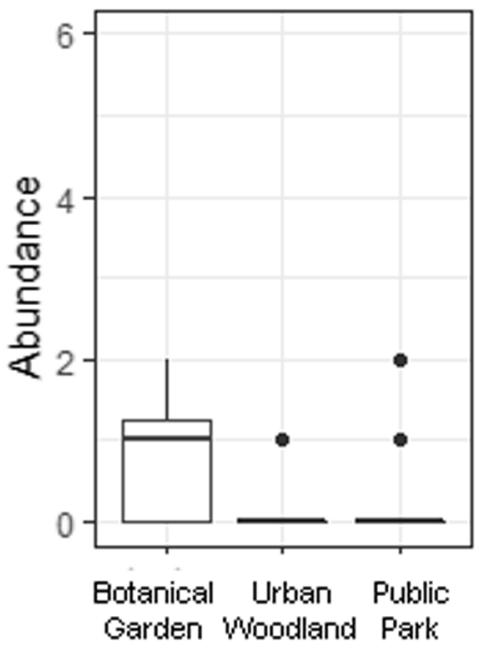

Erigone dentipalpis

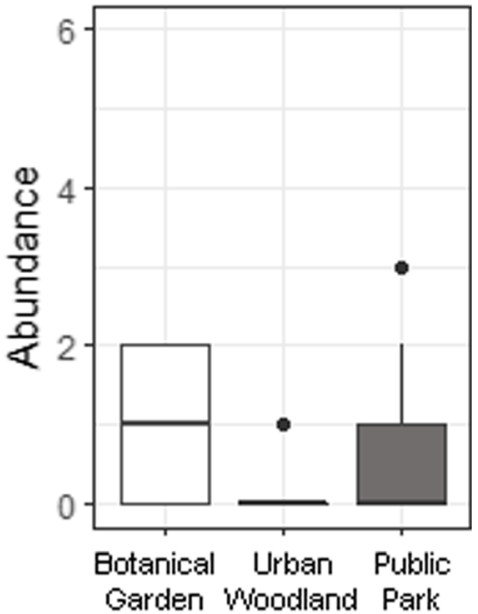

Micrargus subaequalis

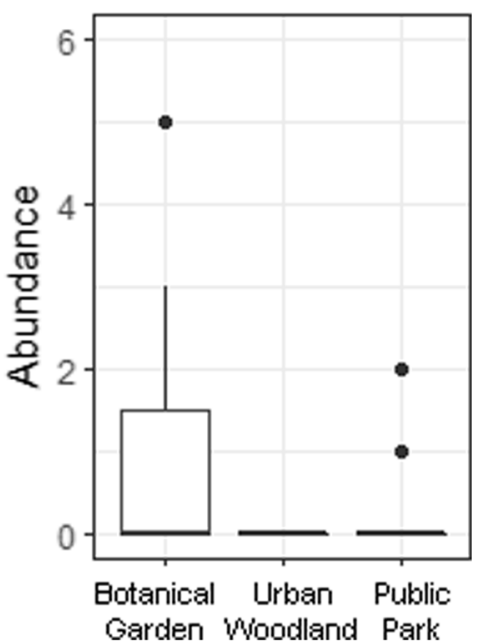

Fig. 8 Boxplot of the most abundant harvestmen species in the studied sites of the three categories of urban greenery

harvestmen differ, showing the highest plasticity and greater synanthropic character. In accordance with previous studies (Pryke and Samways 2009), the highest species richness of the ant and spider communities was found in the botanical gardens, the most intensively managed and most heterogeneous urban greenery of our study. The second habitat in terms of being preferred by ants is urban woodlands, and by spiders - public parks. In the case of harvestmen, however, the highest species diversity was found in public parks, i.e. sites that are, on the one hand, moderately managed, and on the other hand, with the highest direct human pressure due to their main function as recreational areas. In pursuing a deeper view of the profiles of the urban ant and spiders communities, our results show how the species with more specific ecological requirements (i.e. stenotopic and oligotopic native species) restrict their presence to one or two urban green categories.
All three studied urban green categories clearly exhibit their function as refuges of biodiversity in urban ecosystems, but the different manner and intensity of management practices influence the effectiveness of this function. Thus, the large mosaic of diverse microhabitats present in the botanical gardens and woodlands is reflected in the high local species richness and biodiversity. In particular, they provide convenient conditions for species with special ecological requirements (such as, e.g., a high level of soil humidity, presence of wood structures for nesting, xerothermic habitats, etc.), as is observed in the case of some ant (e.g. Formica rufibarbis, Formica rufa or Myrmecina graminicola) and spider species (e.g. the thermophilic species Asagena phalerata and Thanatus sabulosus, the tree linked species Clubiona pallidula or Philodromus albidus, or the xerothermic species of the genus Xerolycosa, Asagena phalerata or Thanatus sabulosus). Notwithstanding, despite both botanical gardens 


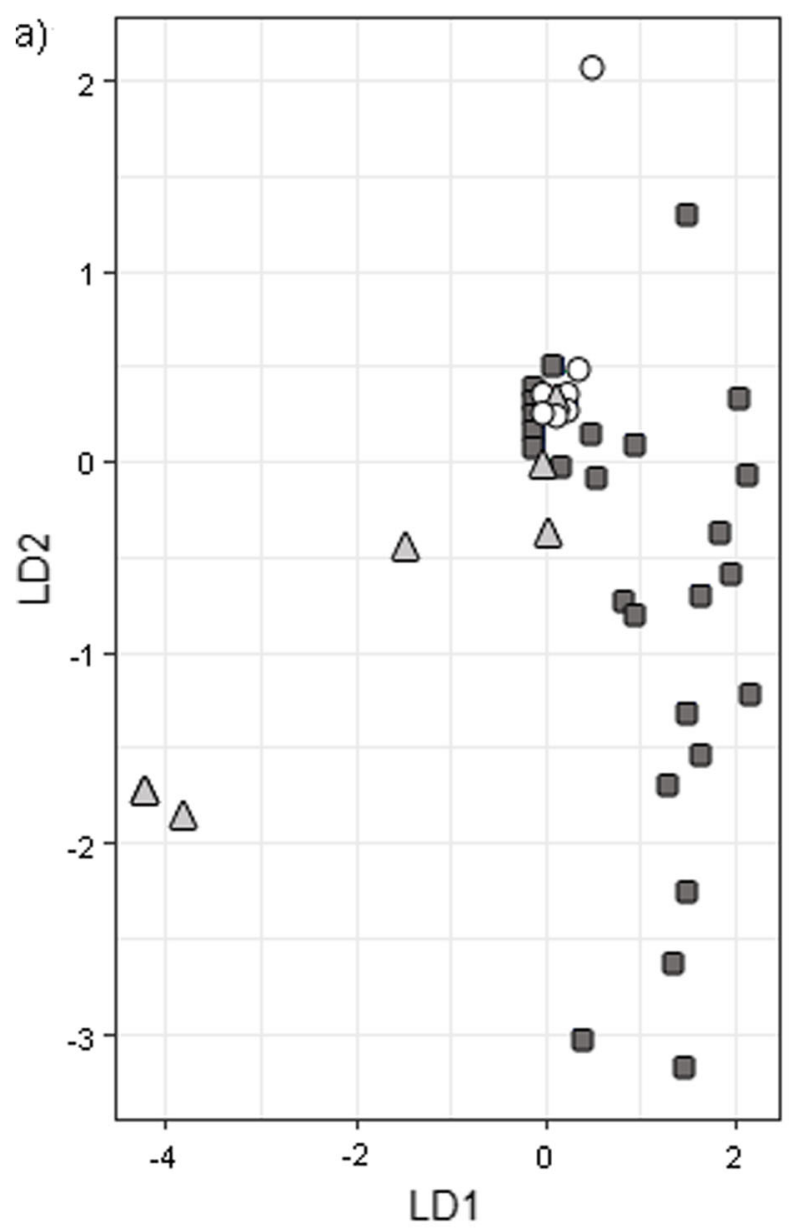

O Botanical Garden

$\triangle$ Urban Woodland

口 Public Park
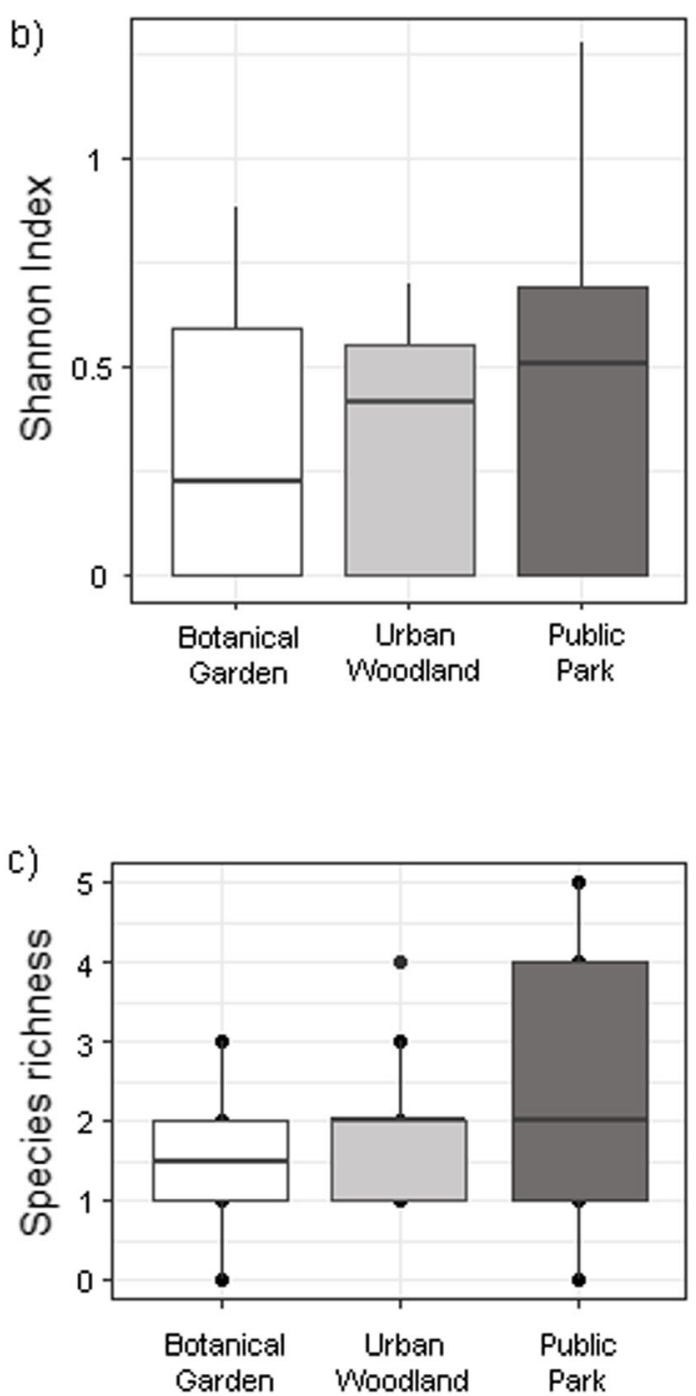

Fig. 9 a Graphical representation of the Linear Discriminant Analyses (LDA) and $\mathbf{b}$ boxplot of Shannon biodiversity Index and $\mathbf{c}$ boxplot of Species richness of the harvestmen community in the studied sites with three urban green categories

are in general under the same intensity of management, our results show a clear difference between them in the number of spider species: the PAS Botanical Garden is the richest in spider species among all the study sites, whereas the UW Botanical Garden is the poorest in this respect. The WU Botanical Garden has a relatively small size which strongly limits the creation of different microhabitats, while the PAS Botanical Garden encompasses a larger number of microhabitats including seminatural forest remnants and large open spaces, additionally enriched in stones and rocks, which create niches for thermophilic species such as Asagena phalerata, Harpactea rubicunda, Ozyptila scabricula and Zodarion germanicum. On the other hand, particular features of the botanical gardens habitat are also conducive to the appearance of exotic, possibly invasive species, such as the ant Pheidole megacephala. An individual found outside most probably came from a greenhouse, where the species was imported together with exotic plants. Climate conditions in Poland rather exclude the possibility of this species wintering outdoors.

Urban woodlands are the most similar to natural forests among the habitats of urban greenery in terms of type of vegetation. Among the three studied categories, they are in a second position in terms of abundance, species richness and diversity of ant communities. Their habitat features, including almost a lack of management, enable a high number of species to be present and, consequently, the relatively high biodiversity values are probably connected with the higher number of suitable habitats for species linked to wood structures or moisture, such as the ant species Temnothorax spp., Myrmica ruginodis or Dolichoderus quadripunctatus. However, the lack of bare ground and/or grassy areas restrict the presence of xerothermic ant species, such as Formica rufibarbis, and 
spider species like Xerolycosa miniata and Xerolycosa nemoralis, or spider species linked to grasslands, i.e. Tenuiphantes tenuis or Zora spinimana.

Public parks are the least suitable habitats for specialist ant and spider species due to the presence of exotic and ornamental plant species, even if their presence is not too dense, lack of compact tree stands, huge extensions of open grassy areas, and intensive management together with recreational functions. On the other hand, species exhibiting anthropophilic tendencies find suitable conditions for living in public parks. Such species are e.g., among ants, the dominating species in the entire Warsaw greenery - Lasius niger and, potentially, the invasive $L$. neglectus, and, among spiders, the dominant Ozyptila praticola, Diplocephalus cristatus and Troxochrus scabriculus. This tendency is especially relevant in the case of invasive species (see Menke and Holway 2006; Menke et al. 2007). Because of their interspecific competition for resources as fairly aggressive species, they lead to changes in the arthropod community structure and decrease the number of native species (Menke et al. 2007). We found such a situation in Warsaw with the invasive Lasius neglectus, whose presence in Ujazdowski Park decreases the abundance of L. niger. However, less aggressive species with more cryptic behaviour may benefit from the appearance of invasive species, which reduce or displace their main competitors. In Warsaw, we observed that the presence of $L$. neglectus favored the presence and abundance of Temnothorax crassispinus due to differences in their foraging hours, which avoided direct contact between both species and the elimination of competitors by L. neglectus.

A different situation was observed for harvestmen, which find suitable conditions in parks. The synanthropic tendency of the species of this group (Czechowski et al. 1981; Rozwałka 2017) together with the large number of microhabitats present in public parks facilitates presence in them. Both xerophilic species (such as Lacinius horridus or Opilio saxatilis) and hygrophilic species (such as L. ephippiatus or Trogulus tricarinatus) can find a refuge in parks due to the presence of walls, paths, trees, shrubs, litter, grass or fountains, typical ornamental facilities of this urban green category. On the other hand, it is worth noting that due to the generally high ecological plasticity of harvestmen (Muster et al. 2014; Rozwałka 2017), almost all species reported in the study occur in each of the studied urban greenery sites.

The habitat structure, understood as the mosaic of microhabitats (their number and spatial distribution in particular green area), determines the local species composition. This mostly influences the presence of stenotopic and oligotopic species in the habitat characteristics due to their highly specific ecological requirements (Levings 1983; Ślipiński et al. 2012). Notwithstanding, not only habitat structure, but also the manner of land use is a very important factor determining local biodiversity. Large losses in park arthropofauna are caused by intensive and systematically conducted gardening and conservation treatments, such as lawn mowing, removing plant biomass (plant clippings, litter, dead parts of trees), sealing tree hollows, etc. The situation is aggravated by the recreational activities occurring in public parks in the summer season, i.e. in the peak season of activity and reproduction of arthropods, when individuals and nests (in the case of ants) are unintentionally destroyed. As a result of this, many species are either scarcely present or absent in the public parks, such as some of the ground nesting species, leaf litter linked species or some dendrophilic species, i.e. the ants Stenamma debile, Myrmecina graminicola or Lasius platythorax, the spiders Pardosa prativaga or P. lugubris and the harvestmen Trogulus tricarinatus. The same effect is observed for those spider species that place their cocoons on the leaves and branches of trees and shrubs, such as Micaria spp. and Philodromus spp. Additionally, removing fallen leaves and branches also constitutes an indirect threat, as the lack of a leaf litter layer combined with increased sun exposure and, subsequently, decreased humidity may severely reduce local populations of more or less hydrophilic species, such as the ant Myrmica ruginodis, the spider Tenuiphantes flavipes or the harvestmen T. tricarinatus. As a result, park arthropofauna is mostly composed of generalist species with a relatively high tolerance of human pressure.

Consequently, the arthropofauna of public parks are strongly susceptible to homogenization and the manifestation of this is the low number of specialist species and the relatively high number of synanthropes (Czechowski and Pisarski 1981; Holway and Suarez 2006). At the same time, the homogenization of the arthropofauna makes it easier for invasive species, such as the ant Lasius neglectus or the harvestmen Nelima semproni and Opilio canestrinii, to colonize the habitat due to decreased competitive pressure from native species. The same trend has been found in other studies carried out in urban ecosystems (Magura et al. 2004; Mabelis 2005; Antonova and Penev 2008) which show how the abundance or number of species of arthropods found in urban parks is significantly lower than in natural and seminatural surrounding areas. The habitat loss due to urbanization and the intensity of management of the greeneries results in a specific community assemblage in all groups of arthropods. As it has been mentioned above, the type of management can particularly affect the survival chances of the large number of stenotopic and oligotopic species (Mabelis 2005; Antonova and Penev 2008; Magura et al. 2008; Duffey 2010; Kaltsas et al. 2014; Radchenko et al. 2019).

In conclusion, we can state that our study shows how the different way and intensity of the management carried out in the urban greenery can determine communities of different groups of the arthropod fauna. The study highlight how, despite the size, location and number of microhabitats of the greenery, human activities carried out in the urban greenery 
affect the presence of specialist species strongly linked to the especific habitat features. Thus, the proper management of urban green areas is critical to enhance their role as refuges of biodiversity in cities where the green patches are almost crucial for the only chance of survival of local outdoor species. Moreover, our study also shows the significance of the faunistic studies to keep updated knowledge on the local biodiversity list and evaluate the effectiveness of the management techniques. It also emphasizes the relevance of the presence of a mosaic of greeneries within the city and their proper intensity of management that maximize the number of local species able to use these urban refugees.

Acknowledgments We would like to thank dr. W. Czechowska for her help with the identification of some material. We would also like to thank to the public authorities of the city of Warsaw for allowing us the sampling of the urban green areas.

Open Access This article is licensed under a Creative Commons Attribution 4.0 International License, which permits use, sharing, adaptation, distribution and reproduction in any medium or format, as long as you give appropriate credit to the original author(s) and the source, provide a link to the Creative Commons licence, and indicate if changes were made. The images or other third party material in this article are included in the article's Creative Commons licence, unless indicated otherwise in a credit line to the material. If material is not included in the article's Creative Commons licence and your intended use is not permitted by statutory regulation or exceeds the permitted use, you will need to obtain permission directly from the copyright holder. To view a copy of this licence, visit http://creativecommons.org/licenses/by/4.0/.

\section{References}

Antonova V, Penev L (2008) Classification of ant assemblages (Hymenoptera: Formicidae) in green areas of Sofia. Acta Zool Bulg, Suppl. 2:103-110

Auguie B (2017) gridExtra: miscellaneous functions for "grid" graphics. $\mathrm{R}$ package version 2.3. https://CRAN.R-project.org/package= gridExtra

Bańkowska R, Czechowski W, Garbarczyk H, Trojan P (1985) Present and prognostical fauna of the housing estate Białołęka Dworska, Warsaw. Mem Zoologi 40:1-168

Bestelmeyer BT, Okin GS, Duniway MC, Archer SR, Sayre NF, Williamson JC, Herrick JE (2015) Desertification, land use, and the transformation of global drylands. Front Ecol Environ 13:2836. https://doi.org/10.1890/140162

Blick T, Komposch Ch (2004) Checkliste der Weberknechte Mittel- und Nordeuropas. Checklist of the harvestmen of central and northern Europe (Arachnida: Opiliones). Version 27. Online at: http://www. AraGes.de/checklist.html\#2004_Opiliones

Burdine JD, McCluney KE (2019) Interactive effects of urbanization and local habitat characteristics influence bee communities and flower visitation rates. Oecologia 190:715-723. https://doi.org/10.1007/ s00442-019-04416-x

Carpintero S, Reyes-López J (2014) Effect of park age, size, shape and isolation on ant assemblages in two cities of southern Spain. Entomol Sci 17:41-51. https://doi.org/10.1111/ens. 12027

Chapman S, Watson JEM, Salazar A, Thatcher M, McAlpine CA (2017) The impact of urbanization and climate change on urban temperatures: a systematic review. Landsc Ecol 32(10):19211935. https://doi.org/10.1007/s10980-017-0561-4

Czechowska W, Czechowski W (1999) Lasius neglectus van loon, Boomsma et Andrasfalvy, 1990 (Hymenoptera, Formicidae), nowy dla Polski gatunek mrówki, w Warszawie. (Lasius neglectus van loon, Boomsma et Andrasfalvy, 1990 (Hymenoptera, Formicidae), a new ant species for Poland, in Warsaw). Prz Zool 43:189-191

Czechowski W (1979) Urban woodland areas as the refuge of invertebrate fauna. Bull Pol Acad Sci 27:179-182

Czechowski W (1991) Comparison of the myrmecofaunas (Hymenoptera, Formicoidea) of tree stands and lawns in Warsaw parks. Fragm Faun 35:179-184

Czechowski W, Pisarski B (eds) (1981) Species composition and origin of the fauna of Warsaw. Part 1. Memorabilia Zool. 34

Czechowski W, Garbarczyk H, Pisarski B, Sawoniewicz J (1982) Species composition and origin of the fauna of Warsaw. Part 2. Ibidem:35

Czechowski W, Pisarski B (1990) Ants (Hymenoptera, Formicoidea) of the Vistula escarpment in Warsaw. Fragm Faun 33:109-128

Czechowski W, Staręga W (1977) Nelima semproni Szalay, 1951 (Opiliones: Gagrellidae) in Warszawa. Fragm Faun 23:13-24

Czechowski W, Garbabczyk H, Pisarski B, Sawoniewicz J (eds) (1982) Species composition and origin of the fauna of Warsaw. Part 3. Memorabilia Zool. 36

Czechowski W, Czechowska W, Palmowska A (1990) Arboreal myrmecofauna of Warsaw parks. Fragm Faun 34:37-45

Czechowski W, Radchenko A, Czechowska W, Vepsäläinen K (2012) The ants of Poland with reference to the myrmecofauna of Europe. Fauna Poloniae 4. Warsaw: Natura optima dux Foundation

Dauber J, Eisenbeis G (1997) Untersuchungen zur Ameisenfauna einer urbanen Landschaft am Beispiel der Stadt Mainz. Mainz Naturwiss Arch 69:237-244

Delfosse E, Iorio E (2009) Contribution à la connaissance des Opilions de France métropolitaine (Arachnida: Opiliones I. Bull Soc Linn Bord. 144 (N.S.) (37):99-106

Duffey E (2010) Spider habitat classification and the development of habitat profiles. Bull Br Arachnol Soc 15:1-20

Guénard B, Cardinal-De Casas A, Dunn RR (2015) High diversity in an urban habitat: are some animal assemblages resilient to long-term anthropogenic change? Urban Ecosyst 18:449-463. https://doi.org/ 10.1007/s11252-014-0406-8

Haase H, Balkenhol B (2015) Spiders (Araneae) as subtle indicators for successional stages in peat bogs. Wetl Ecol Manag 23:453-466. https://doi.org/10.1007/s11273-014-9394-y

Holway DA, Suarez AV (2006) Homogenization of ant communities in Mediterranean California: the effects of urbanization and invasion. Biol Conserv 127:319-326. https://doi.org/10.1016/j.biocon.2005. 05.016

Hothorn T, Bretz F, Westfall P (2008) Simultaneous inference in general parametric models. Biom J 50(3):346-363

Kabisch N, Qureshi S, Haase D (2015) Human-environment interactions in urban green spaces - a systematic review of contemporary issues and prospects for future research. Landsc Urban Plan 50:25-34. https://doi.org/10.1016/j.eiar.2014.08.007

Kabisch N, Strohbach M, Haase D, Kronenberg J (2016) Urban green space availability in European cities. Landsc Urban Plan 70:586596. https://doi.org/10.1016/j.ecolind.2016.02.029

Kaltsas D, Panayiotou E, Chatzaki M, Mylonas M (2014) Ground spider assemblages (Araneae: Gnaphosidae) along an urban-rural gradient in the city of Heraklion, Greece. Eur J Entomol 111(1):59-67. https://doi.org/10.14411/eje.2014.007

Kindt R, Coe R (2005) Tree diversity analysis. A manual and software for common statistical methods for ecological and biodiversity studies. World Agroforestry Centre (ICRAF), Nairobi. ISBN 92-9059-179-X

Krzyżanowska E, Dziabaszewski A, Jackowska B, Staręga W (1981) Spiders (Arachnoidea, Aranei) of Warsaw and Mazovia. Memorabilia Zool 34:87-110 
Kuznetsova A, Brockhoff PB, Christensen RHB (2017) lmerTest Package: Tests in Linear Mixed Effects Models. J Stat Softw 82(13):1-26. https://doi.org/10.18637/jss.v082.i13

Levings SC (1983) Seasonal, annual, and among-site variation in the ground ant community of a deciduous tropical forest: some causes of patchy species distributions. Ecol Monogr 53(4):435-455. https:// doi.org/10.2307/1942647

Luniak M, Pisarski B (eds) (1982) Animals in urban environment. Ossolineum, Wrocław

Luniak M (1990) Urban ecological studies in Central and Eastern Europe. Wrocław: Ossolineum

Mabelis AA (2005) Green infrastructure of a city and its biodiversity: take Warsaw as an example. Fragm Faun 48:231-247

MacGregor-Fors I, Escobar F, Rueda-Hernández R, Avendaño-Reyes S, Baena LM, Bandala MV, Chacón-Zapata S, Guillén-Servent A, González-García F, Lorea-Hernández F, Montes de Oca E, Montoya L, Pineda E, Ramírez-Restrepo L, Rivera-García E, Utrera-Barrillas E (2016) City "green" contributions: the role of urban greenspaces as reservoirs for biodiversity. Forests 7

Magura T, Tothmeresz B, Molnar T (2004) Changes in carabid beetle assemblages along an urbanisation gradient in the city of Debrecen, Hungary. Landscape Ecol 19:747-759

Magura T, Tothmeresz B, Hornung E, Horvath R (2008) Urbanisation and ground-dwelling invertebrates. In: Wagner LN (ed) Urbanisation: 21st century issues and challenges. Nova Science Publishers, New York, pp 213-225

Magura T, Horváth R, Tóthmérész B (2010) Effects of urbanization on ground-dwelling spiders in Forest patches, in Hungary. Landsc Ecol 25(4):621-629. https://doi.org/10.1007/s10980-009-9445-6

Matuszkiewicz W (1966) Potencjalna roślinność naturalna Kotliny Warszawskiej (potential natural vegetation of the Warsaw Basin). Materiały Zakładu Fitosocjologii Stosowanej U W, 15:1-12

McKinney ML (2008) Effects of urbanization on species richness: a review of plants and animals. Urban Ecosyst 11:161-176. https:// doi.org/10.1007/s11252-007-0045-4

Menke SB, Holway DA (2006) Abiotic factors control invasion by argentine ants at the community scale. J Anim Ecol 75:368-376. https://doi.org/10.1111/j.1365-2656.2006.01056.x

Menke SB, Fisher RN, Jetz W, Holway DA (2007) Biotic and abiotic controls of argentine ant invasion success at local and landscape scales. Ecology 88:3164-3173. https://doi.org/10.1890/07-0122.1

Moorhead LC, Philpott SM (2013) Richness and composition of spiders in urban green spaces in Toledo, Ohio. J Arachnol 41:356-363. https://doi.org/10.1636/P12-44.1

Muster C, Meyer M, Sattler T (2014) Spatial arrangement overrules environmental factors to structure native and non-native assemblages of synanthropic harvestmen. PLoS One 9(3):e90474. https://doi.org/ 10.1371/journal.pone.0090474

Nentwig W, Blick T, Gloor D, Hänggi A, Kropf C (2018) Araneae spiders of Europe. https://araneaee.nmbe.ch.Visited 01.2019

Oksanen J, Guillaume Blanchet F, Friendly M, Kindt R, Legendre P, McGlinn D, Minchin PR, O'Hara RB, Simpson GL, Solymos P, Stevens MHH, Szoecs E, Wagner H (2017) Vegan: community ecology package. R package version 2.4-4. https:/CRAN.Rproject.org $/$ package $=$ vegan

Oleszczuk M (2017) Spider fauna (Araneae) of the Sieraków Landscape Park (Central Poland) - preliminary data. Fragm Faun 60(1):53-60

Pinheiro J, Bates D, DebRoy S, Sarkar D (2017) Nlme: linear and nonlinear mixed effects models. R package version 3.1-131, URL http:// CRAN.R-project.org/package $=$ nlme

Pisarski B (1982) Ants (Hymenoptera, Formicoidea) of Warsaw and Mazovia. Memorabilia Zool 36:73-90

Pisarski B, Czechowski W (1978) Influence de al pression urbaine sur la myrmécofaune. Memorabilia Zool. 29:109-128

Pryke JS, Samways MJ (2009) Recovery of invertebrate diversity in a rehabilitated city landscape mosaic in the heart of a biodiversity hotspot. Landsc Urban Plan 93:54-62. https://doi.org/10.1016/j. landurbplan.2009.06.003

Radchenko AG, Stukalyuk SV, Netsvetov MV (2019) Ants (Hymenoptera, Formicidae) of Kyiv. Entomol Rev 99(6):753-773. https://doi.org/10.1134/S0013873819060058

R Core Team (2017) R: A language and environment for statistical computing. R version 3.4.2 (2017-09-28) - "Short Summer". Austria, Vienna: R Foundation for Statistical Computing

Rozwałka R (2017) Kosarze (Opiliones) Polski. (Harvestmen (Opiliones) of Poland). Poligrafia Salezjańska. Kraków

Rozwałka R, Staręga W (2012) The invasive harvestmen Opilio canestrinii (Thorell, 1876) (Opiliones: Phalangiidae) in Poland. Fragm Faun 55(2):161-168

Seifert B (2000) Rapid range expansion in Lasius neglectus (Hymenoptera, Formicidae) - an Asian invader swamps Europe. Mitteilungen des museums für Naturkunde Berlin. Dtsch entomol Z 47:173-179

Ślipiński P, Żmihorski M, Czechowski W (2012) Species diversity and nestedness of ant assemblages in an urban environment. Eur J Entomol 109:197-206. https://doi.org/10.14411/eje.2012.026

Starega W (2004) Interessante Weberknechtfunde aus Polen (Arachnida: Opiliones). Arachnol Mitt 27:78-88

Trigos-Peral G (2015) Papel de las zonas urbanas en las estrategias globales de conservación usando hormigas como bioindicadores. $\mathrm{PhD}$ thesis. University of Córdoba, Spain

Venables WN, Ripley BD (2002) Modern applied statistics with S. Fourth Edition. Springer, New York. ISBN 0-387-95457-0

Vepsäläinen K, Ikonen H, Koivula MJ (2008) The structure of ant assemblages in an urban area of Helsinki, southern Finland. Ann Zool Fenn 45:109-127. https://doi.org/10.5735/086.045.0203

Wawer W (2016) Pajaki (Araneae) Parku Skaryszewskiego w Warszawie (Spiders (Araneae) of Park Skaryszewski in Warsaw). Jerzy Romanowski (Eds.), Park Skaryszewski w Warszawie. Uniwersytet Kardynała Stefana Wyszyńskiego. Przyroda i użytkowanie, pp 161-168

Wickham H (2009) ggplot2: elegant graphics for data analysis. SpringerVerlag New York

Wickham H (2017) Stringr: simple, consistent wrappers for common string operations. $\mathrm{R}$ package version 1.2.0. https:/CRAN.Rproject.org/package=stringr 